\title{
FOREIGN CAPITAL DESTINATIONS: BALTIC STATES VERSUS INDIA
}

\author{
Manuela Tvaronavičiené $\dot{1}^{1}$, Virginija Grybaité ${ }^{2}$, Renata Korsakiené $\dot{3}^{3}$ \\ Vilnius Gediminas Technical University, Saulettekio al. 11, LT-10223 Vilnius, Lithuania \\ E-mails: ${ }^{1}$ manuela@vv.vgtu.lt; ${ }^{2} v i r g i @ v v . v g t u . l t ;{ }^{3} v v f i e v k @ v v . v g t u . l t$ \\ Received 17 November 2007; accepted 20 April 2008
}

\begin{abstract}
The presented paper aims to elaborate which factors have the biggest influence on investment decisions while choosing between India and the new EU members - Lithuania, Latvia and Estonia. For analysis purpose the Baltic States have been juxtaposed to India, as the latter represents emerging market, and, according to almost unanimous prognosis, is one of the main FDI destinations for the nearest future. The Baltic States are considered as attractive recent entrants of the EU demonstrating high growth and representing new unsaturated market. FDI inflows into those rather different countries started in approximately 1991, thus driving forces behind international capital movement serve as object of scientific interest. The data retrieved and used for considerations embraces period from 1999 to 2008. Authors ground premises about significance of certain sets of driving factors and use multi-criteria evaluation methods to indicate driving forces determining propensity to invest into the Baltic States' region and India. Results of speculative analysis are supposed to add to better understanding of contemporary investment behaviour of well-developed economies.
\end{abstract}

Keywords: FDI, the Baltic States, India, multi-criteria evaluation.

\section{Introduction: selection of indicators for multi-criteria calculus}

In the scientific literature many theories could be found, trying to explain why firms undertake foreign investments. The mostly referred are the following ones: Eclectic paradigm, the neoclassical model and the new trade theory. Recall, that the eclectic or OLI paradigm, created by Dunning $(1977,1988)$, states that investors are driven by 3 determinants: ownership, location and internalisation (OLI). The ownership advantage occurs when superior technology and management knowledge allow the firm to compete on a foreign market in spite of the transaction costs. Location advantage occurs if the host economy can provide large markets. Here we could clarify that from our point of view, enlargement of market for investing country could be ensured in two cases. In the first case, if recipient country is big in geographical or population sense, and in the second case, when country is even a small one but displays stable economic growth it promises additional market capacity for investor. Location advantages include institutional regulations as well. Those in sensu latu embrace variety of characteristics, starting from legal framework, finishing with national bureaucracy and transparency dimensions, which is difficult to measure. According to Yoshitomi, Graham (1996), the location-specific advantages are largely exogenous at the time that the decisions for the FDI are made. Neoclassical model suggests that FDI behaviour has been explained by comparative advantage, when investors base location decisions on capital and labour cost minimization (e.g. Kottaridi 2005). The basis of this model is profit maximization through production costs minimization and maximization of income. New trade and new economic geography theories have emerged adding elements of increasing returns to scale and differentiated production. If different levels of labour intensity characterize different stages of the production process, a reasonable strategy would be to allocate the stages with high labour intensity to countries with low levels of labour costs and the stages requiring lots of skills or capital to high-income countries. Not going into further elaboration of rather known theories, we aim at another issue. The question is for what reasons some destinations are more attractive than others; and 
if the reasons can be listed, why FDI still remain disseminated. Decisions to invest are based on some arguments. We seek to trace how strongly specific factors affect the decision about investing. To put it in a different way, we would like to find out what main investment driving forces are, and how strongly they affect decision-making process. In order to detect FDI driving forces to completely different geographical regions - the Baltic countries and India - the above referred theories were employed and the following aspects were distinguished: economic stability, institutional hindrance, costs and socio-geographical characteristics. As it could be noticed, FDI driving forces could be very different: some of them are qualitative, some - quantitative, also some are just emotional and based on intuition of investor. FDI driving forces to the recent EU entrants, like Lithuania, Latvia and Estonia, might differ from stimuli to invest into low-cost emerging economies like India. The Baltic markets could be attractive because of their development rates, educational level, and stability. Those countries, even being small, might have growth potential, low prices and other advantages.

Statistical data show that among those out of 10 major investors into the Baltic States and India, four are the same: Germany, the UK, USA and Netherlands (Table 1).

Table 1. Main investing countries

\begin{tabular}{cll}
\hline & \multicolumn{1}{c}{ BALTIC STATES } & \multicolumn{2}{c}{ INDIA } \\
\hline 1 & Sweden & Mauritius \\
\hline 2 & Russian Federation & USA \\
\hline 3 & Germany & Netherlands \\
\hline 4 & Denmark & Japan \\
\hline 5 & Finland & UK \\
\hline 6 & USA & Germany \\
\hline 7 & Estonia & Singapore \\
\hline 8 & Netherlands & France \\
\hline 9 & Norway & South Korea \\
\hline 10 & UK & Switzerland \\
\hline
\end{tabular}

Source: http://www.indiastat.com; http://www.stat.gov.lt/lt; http://www.csb.gov.lv; http://www.stat.ee

It means, that same four investors diversify their investments among the Baltic countries and India. That confirms our assumption that different sets of driving forces determine inclination to tackle the new EU entrants and emerging India. Presented research will be comprised of the following stages. At first, set of indicators, reflecting economic stability, institutional hindrance, costs and socio-geographical characteristics are being selected and some specific trends for considered period commented. The second stage will be devoted to simulation of significance variants. Application of multi-criteria methods will allow us to estimate propensity to invest into two destinations of interest when driving forces expressed in our set of indicators change their driving strength. The results of analysis let us assume some state policy implications concerning FDI stimulation, or rather, reflect if such policy is rational at all. Hence, in order to trace driving forces of FDI we compose a set of indicators. We observed chosen indicators not only for India and the Baltics, i.e. destination countries, but traced main tendencies of their change for investors- Germany; the UK, USA, and the Netherlands - as well. The set of indicators was selected in a way it could reflect macroeconomic and institutional conditions, level of cost and characterize socio-geographic conditions of considered countries. In order to be suitable for further mathematical analysis, indicators should comply with the following criteria. Hence, indicators meet integrity principle, i.e. may be integrated into one system, as do not oppose or contradict each other. All indicators in the process of analysis could arrange hierarchical structure. Indicators should be universal in a sense being applicable for evaluation of rather different countries versus being tailored for reflecting certain region specifics. Indicators should have obtainable numerical measures. Indicators included into relevant set or system and being used for further analysis are presented below (Table 2).

Table 2. Indicators, included into system, being used for further multi-criteria speculations

INDICATORS OR SET OF CONSIDERED FDI DRIVING FORCES

Macroeconomic and institutional conditions

1. GDP growth, percent

2. GDP per capita growth, percent

3. Inflation, percent

4. Unemployment rate, percent

5. Taxes (income tax and VAT), percent

6. Number of procedures to start business

7. Number of days to start business

Costs

8. Activity costs (energy)

9. Costs to start business

10. Hourly compensation

Socio-geographical

11. Population growth, percent

12. Distance

13. Area

14. Educational level, literacy rates, percent 


\section{Some factor trends of capital donors' and recipients' countries}

The first group of indicators is supposed to reflect economic growth (GDP growth, GDP per capita growth) economic stability (inflation, unemployment rate) and institutional conditions of business' performing (taxes, bureaucratic hindrance-number of procedures and days required for business starting). Allowing that list is neither complete nor out of critics, we still point out that those indicators comply with purpose and adopted approach of research. Inclusion investors' data into research let us deepen our understanding of driving interests of going to different destinations as similarities and differences of investors and recipients are clearly displayed. Let us glance at one of major macroeconomic indicators, i.e. real GDP growth taken for the last decade (Fig. 1).

Fig. 1 reveals that during considered period the investors converge gradually and flock at relatively low rates of growth in real terms. The Baltic countries and India performing the role of recipients of capital flows perform considerably better in a sense of growth. Hence, slower growth of developed countries might be considered as sufficiently important reason making more rapidly growing markets appeal for investments, even not considering reason of that growth (Tvaronavičienè 2006; Tvaronavičius and Tvaronavičienè 2008; Tvaronavičienè and Degutis 2007; Tvaronavičienė and Grybaite 2007). The Baltic countries during half of considered period managed outperform emerging India and in some years grew 6 times faster than the EU statistical average. USA growth rates as well converged to those of the EU.

Despite the fact, that we included several indicators, reflecting growth (including GDP growth per capita) into our analysis, we intend to provide consideration only for more interesting tendencies. Statistical data on inflation (Fig. 2) clearly reflect that growth of the Baltics and India is being followed by increasingly growing inflation (that is especially vivid in the Baltic countries). Different explanations for the phenomenon could be found, starting from global energy, food and other resources costs pushed inflation, following by shift of trade towards the EU (Ginevičius et al. 2007), increased borrowing and governmental spending. Not going into discussion about core reasons, we need to admit that the Baltic states showed themselves like the most vulnerable ones, and that, we suppose, should be taken into account by potential investors.

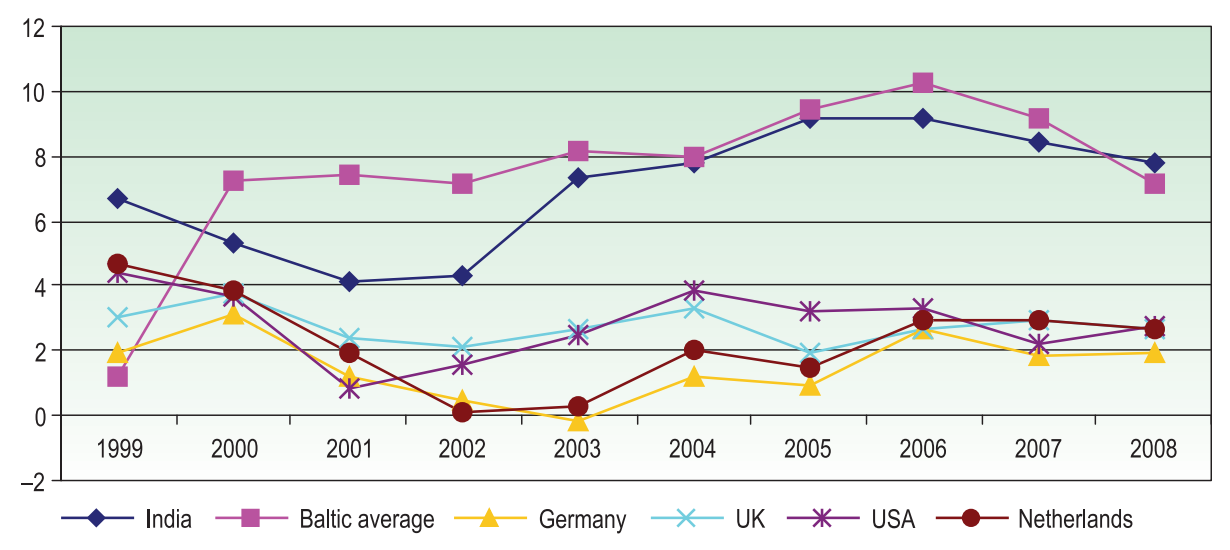

Fig. 1. Real GDP growth, percent Source: IMF statistics, 2007

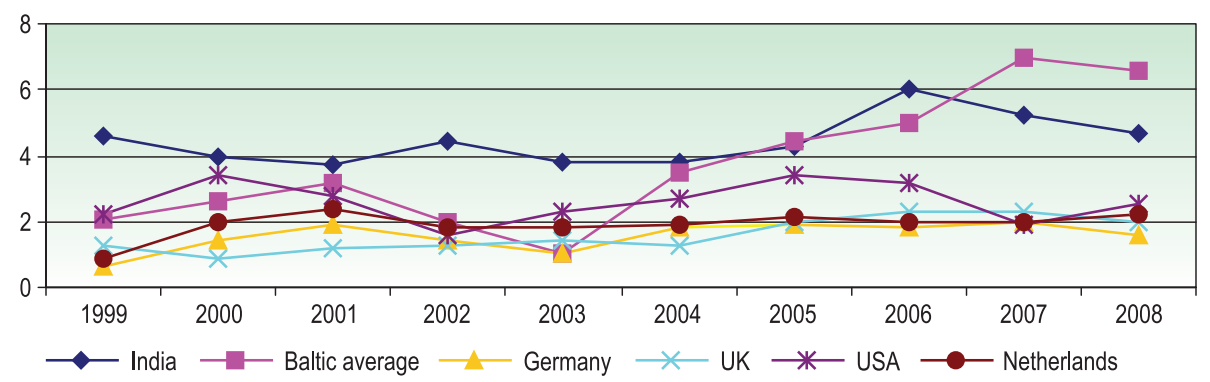

Fig. 2. Consumer price inflation, percent

Source: IMF statistics, 2007 


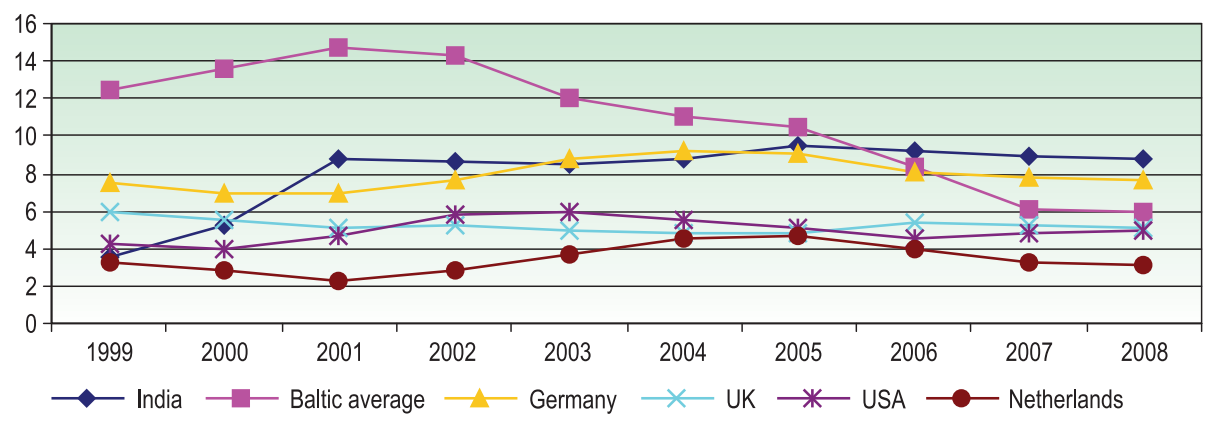

Fig. 3. Unemployment rates, percent Source: IMF statistics, 2007

Changes in unemployment rates are rather different in all considered, i.e. capital donor and recipient countries (Fig. 3). Diminishing unemployment in the Baltics coincides with high economic growth rates but still can not straightforwardly be treated as exclusively positive. Increasing emigration, which adds considerably to improvement of this indicator, is treated controversially and its long-term effects remain under harsh discussion (Tvaronavičienè, Ginevičius 2005). Nevertheless, unemployment rate is rather unanimously attributed to major macroeconomic indicators signalling about economic health of any country.

Continuous discussion about impact of taxation on capital attraction could be presented. Despite that, we do not share opinion about the crucial role of tax burden in affecting international capital flows (Ginevičius, Tvaronavičienè 2003, 2004) still paying tribute to the factor, which some authors emphasise as an urgent one, presenting differences in tax burdens in considered countries (Fig. 4).

Surprisingly, India being attractive destination of FDI could not be attributed to low tax countries. That only confirms speculations about complexity of a phenomenon under elaboration. As concerns number of pro- cedures to start business, India is the most bureaucratized, and Netherlands the most expensive (The World Bank group). As it was presented above, India does not have comparative advantage in institutional environment area. Let us juxtapose labour costs in considered countries. Fig. 5 illustrates difference between India and the Baltic States and a gap between those two FDI destinations and capital investing countries.

Labour costs in the Baltic countries are still 5 times greater than in India. During the last 10 years labour

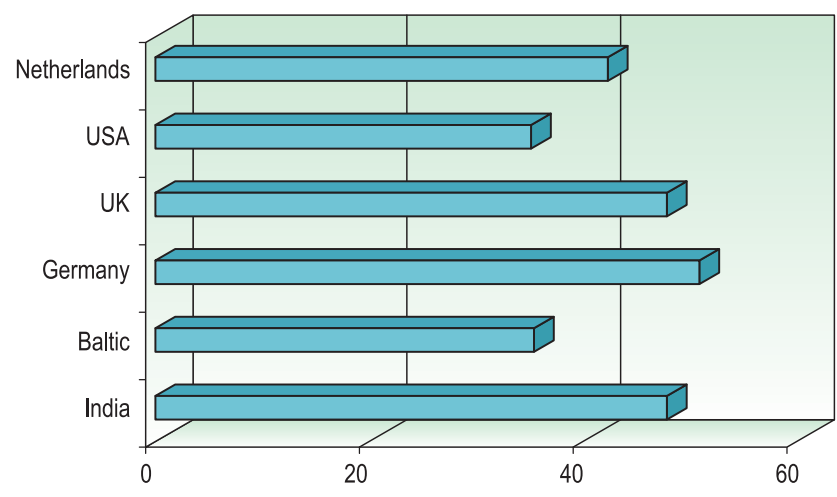

Fig. 4. Income tax and VAT, percent, 2007

Source: The complete worldwide tax \& finance site http://www.worldwide-tax.com

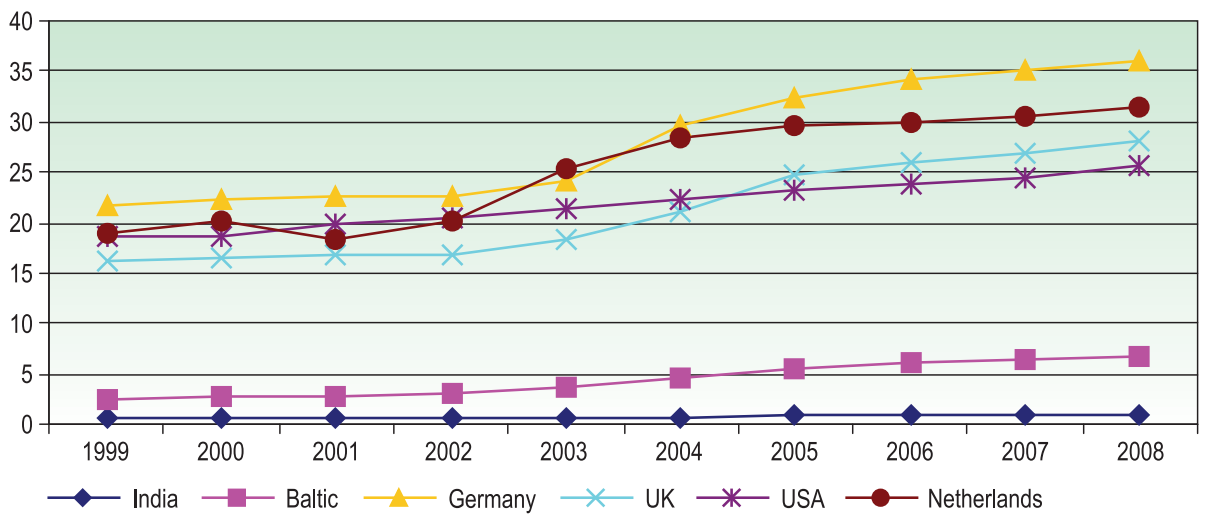

Fig. 5. Hourly compensation costs in manufacturing, US dollar/hour

Source: Steelmaking economics. International labour cost comparisons: http://www.steelonthenet.com/labour_cost.html; EUROSTAT 
costs in industrialized countries almost doubled. Keeping into account inflation rates in India, and especially in the Baltic countries, one can hardly expect that rather a flat curve of labour cost growth would not become steeper. To conclude, at the current moment India certainly has a comparative advantage in labour costs, but what might be peculiar it does not have that advantage in electricity costs, which are very close to those in capital recipient and capital donor countries (The Energy and Resources Institute).

Not commenting on other indications, which are less expressive but not less important, we undertake the main part of our analysis. The analysis contains simulation of different approaches (Tvaronavičienè et al. 2008) towards presented groups of indicators (Table 2) inducing propensity to invest into the Baltic States or/ and India. In the analysis we employ data from EUROSTAT, IMF, UN and World Bank, time period of 10 years - from 1999 to 2008 - is being embraced.

\section{Analysis methods}

Chosen regions are rather different. Indicators, chosen for their characteristics obtain different values, and even trends of change. In order to detect what aspects of recipient country seem of the most importance to investor, we are going to simulate weights of indicators included into the set (Table 2). Attributing weights to the indicators we will come to one integrating value for one statistical year. The following methods of multicriteria evaluation are used:

- Simple Additive Weighting (SAW);

- Multifunctional complex evaluation (MCE) method.

The main difference between those methods is that they normalize (convert indicators being maximized and minimized into one direction changing ones) values of included into system indicators differently (Ginevičius et al. 2005; Ginevičius and Podvezko 2005; Zavadskas et al. 2003). The problem of choosing multifunctional evaluation method, taking into account variety of methods, their applicability, suitability, etc. is not discussed in this paper.

Multifunctional evaluation supposes combination of mathematical product of two multiples.

$$
\sum_{i=1}^{m} w_{i}=1
$$

where $w_{i}$ - weigh of $i$-element; $m$ - number of elements $(i=1, \ldots, \mathrm{n})$.
For the evaluation of FDI attractiveness the authors used annual data of indicators $r_{i j}(i=1, \ldots m ; j=1, \ldots n)$, $m$ - number of indicators, $n$ - number of countries. In our case $m=14, n=6$.

Multifunctional evaluation methods require positive values of $r_{i j}$ indicators. Thus, for negative numbers (e. g., inflation) respective formula has been applied:

$$
\bar{r}_{i j}=r_{i j}+\min _{j}\left|r_{i j}\right|+1 .
$$

Multifunctional evaluation method also requires that all indicators would move in the same direction, that means would be maximized or minimized. The best values of first ones are the highest, and the others - the smallest. The next step is normalisation of values of all the indicators, that is converting all values that are being minimized or maximized to one single direction value. Each method normalizes index values differently. Indicators that are maximized: GDP growth, GDP per capita, Population growth, Area, Educational level. The other indicators are minimized (see Table 2).

Attempting to take into account different importance of different groups of indicators, simulations have been performed. Three assumptions or hypotheses have been tested.

1. All indicators have equal weights, it means, we admit that investors treated all indicators as equally important.

2. All importance is delegated to macroeconomic and institutional indicators and minimum weights are attributed to all other indicators included into a set.

3. All importance is delegated to cost indicators and minimal weights are applied to all other indicators.

Results of each simulation are to be presented graphically. Data of the Baltics and India were used for simulations and received aggregate indicators juxtaposed to statistical cumulative FDI during considered period. Recall that the main investors to the Baltic countries and India are: Germany, the UK, USA and the Netherlands.

\subsection{Mathematical simulations for the first assumption}

In the first simulation weights of all selected indicators are equal. Recall the first assumption or hypothesis 1 is that FDI flows are determined by factors, which impact on investment decision equally. Results of calculations by applying SAW and MCE multi-criteria methods are presented in Figs. 6 and 7 respectively. According to both variants of calculation India obtains higher values of aggregated indicator, what should signal that it is slightly more attractive for investors. 


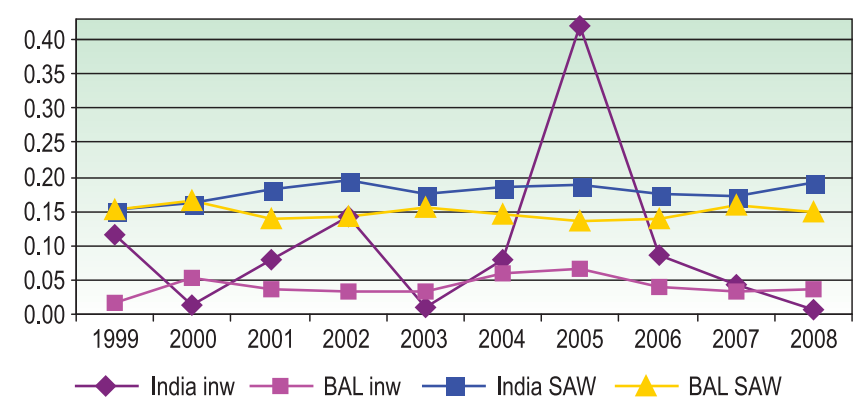

Fig. 6. FDI growth rates vs aggregated index SAW (the first assumption)

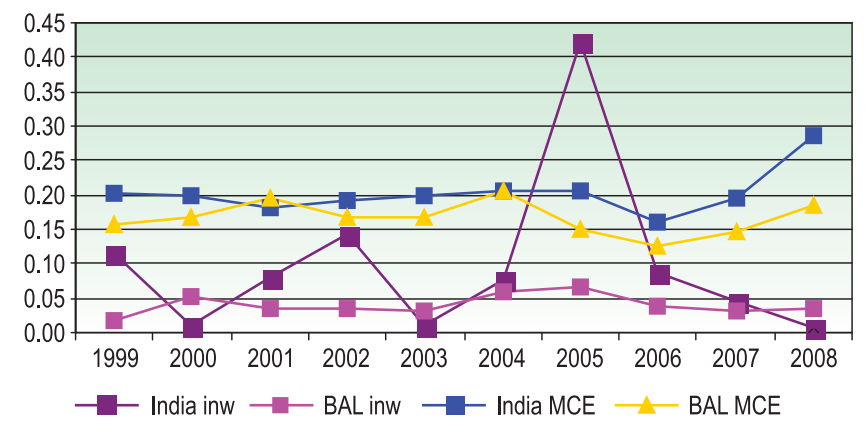

Fig. 7. FDI growth rates vs aggregated index MCE (the first situation)

Peculiar notice concerning the first assumption is that FDI inflow rates, expressed in percentage terms do not correlate vividly with aggregate index, computed by both SAW and MCE method, especially in case of India. The latter observation leads to two major conclusions. The first, hypothesis about equal importance of all factors can not explain investment behaviour; and the second, FDI growth rates in the Baltics suggest that investors might seek to diversify their investments irrespective of obtained benefits.

\subsection{Mathematical simulations for the second assumption}

The second assumption (or hypothesis 2), according to which simulations using SAW and MCE multi-criteria methods are performed, states that macroeconomic and institutional conditions play the crucial role in FDI attraction; i.e. they could be considered as major investment driving forces. Hence, in mathematical simulations of indicators' significances $70 \%$ of weights are distributed between economic and institutional indicators. The other indicators included into considered set of driving forces receive the minimum points to make multiple criteria calculus feasible. According to results of SAW and MCE methods, we receive a slightly different view: countries are getting closer in terms of aggregate indicators (Figs. 8, 9).

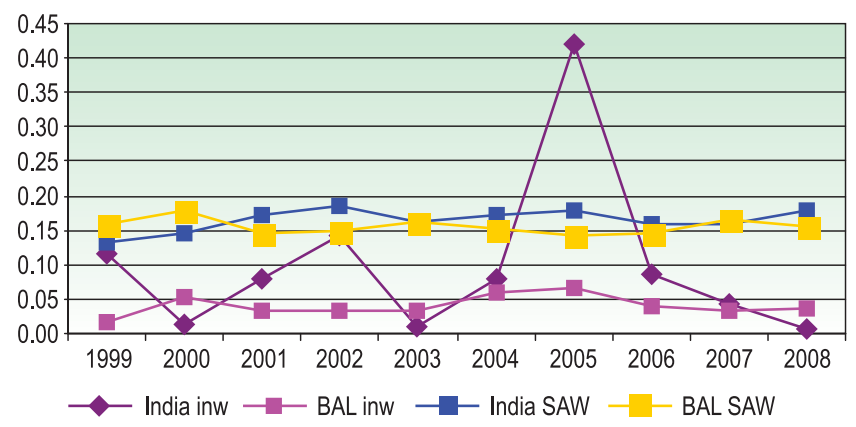

Fig. 8. FDI growth rates vs aggregated index SAW (the second situation)

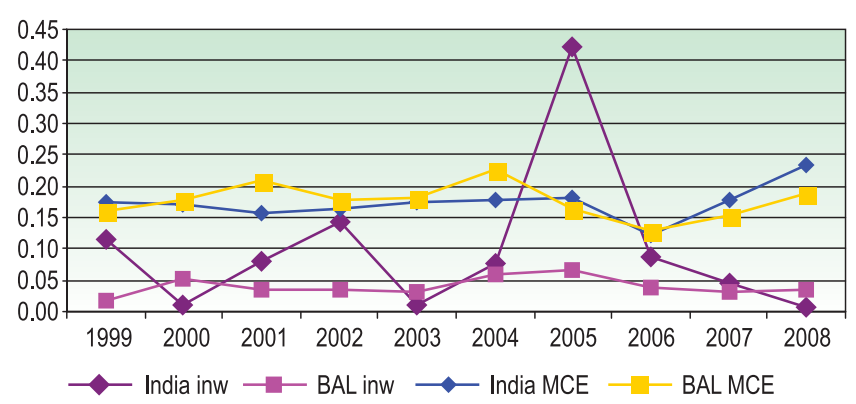

Fig. 9. FDI growth rates vs aggregated index MCE (the second situation)

Newly obtained insight, determined by application of the assumption of macroeconomic environment significance for investment decisions, is that the Baltic States, in case of MCE method application, obtain higher attractiveness compared to India. Nevertheless, fluctuations of FDI growth rates, especially in India, cannot be explained by macroeconomic and institutional situation, mainly.

\subsection{Mathematical simulations for the third assumption}

The third simulation is being grounded on the assumption that the most important, among others, FDI driving forces are low costs in capital recipient countries. Simulation of the third variant aims to verify attractiveness of the Baltic States and India, when economical, institutional and socio-geographical driving forces are considered as less important in comparison with low cost factors. Hypothesis 3 is that indicators reflecting cost structure affect inward FDI flows, thus interrelation between FDI growth rate and aggregated indicator is expected. Results of calculations by applying SAW and MCE multi-criteria methods provide us with similar view (Figs. 10, 11). In case when costs are important, India is much more attractive than the Baltic States.

To generalize, despite the fact that the Baltic States still have considerably lower if compared to investors' 


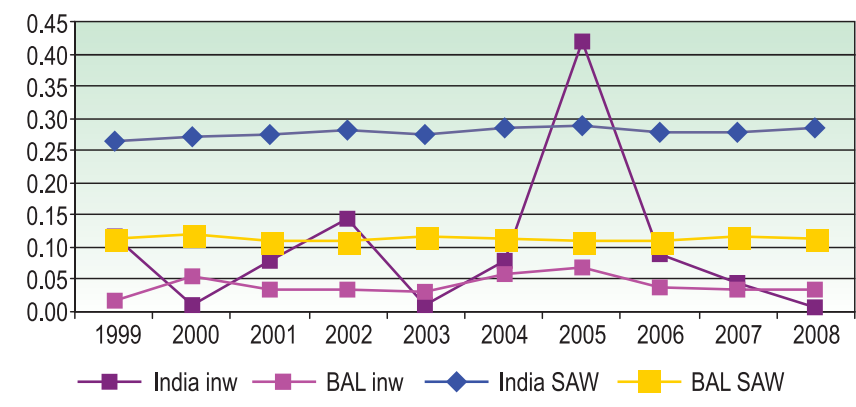

Fig. 10. FDI growth rates vs aggregated index SAW (the third situation)

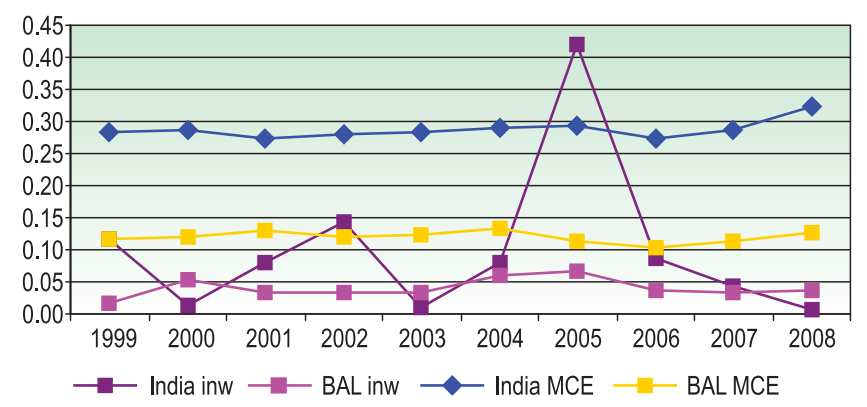

Fig. 11. FDI growth rates vs aggregated index MCE (the third situation)

labour costs (Fig. 5), India's even lower labour compensation determines "off-shoring" of labour intensive production. Capital-intensive production is not worth to be off-shored, as energy costs in India have no distinctive advantage. The third simulation let us completely reveal driving forces of investments to different destinations. Investors, to our mind, diversify their investments in one case (the Baltic States') seeking stability and growth, in the other case (India's) aiming to benefit from low labour costs outsourcing or offshoring labour-intensive activities. As concerns methods of multi-criteria evaluation, we need to admit, that both SAW and MCE provided us with rather similar results. In the second situation, attractiveness of the Baltic States and India was indicated as being close enough, although SAW indicated India as being more attractive, while according to MCE the Baltic States received higher scores in that sense.

\section{Conclusions}

Scientific literature provides many theories about FDI. Different factors, attracting FDI to countries are discussed. The main theories are eclectic, neoclassical and new economic geography theories. Eclectic theory or OLI paradigm suggests that investors are investing abroad because of three main reasons: looking for OLI - ownership, location and internalisation advan- tage. Neoclassical model supports cost minimization idea. It is stated that the main FDI driving force is labour cost minimization, while most of production is labour intensive. According to this theory, it is logic to shift the production of high-income and laboursaving new products from investing country to other countries. According to the new economic geography theory firms are interested in scale economies.

To understand which factors affect FDI decision while investing into completely different destinations, i.e. the new EU entrants - the Baltic States and India, mathematical simulation of importance of investment driving forces model was suggested. Theoretically grounded set of indicators, representing investment factors were grouped into three sections: economic and institutional, costs, and socio-geographical.

Results of research have led to the following generalizations:

First, different driving forces are not equally important for different destinations.

Second, the Baltic States and India are not competing but complementary destinations, when investor is concerned about rather stable growth of market.

Third, in case of outsourcing or off-shoring labour intensive production, India appears to be a more attractive investment destination.

It is worth to mention, that institutional environment appeared to be not so important while choosing between those different investment options. Hence, we tend to claim, that specific policies oriented towards FDI stimulation may show later as had been not efficient enough.

\section{References}

Central Statistical Bureau of Latvia. Available from Internet: $<$ http://www.csb.gov.lv>.

EUROSTAT. Available from Internet: < http://epp.eurostat. ec.europa.eu>.

Datanet India. Available from Internet: < http://www.indiastat.com>.

Dunning, J. H. 1977. Trade location of economic activity and the multinational enterprise: A search for an eclectic approach, in B. Ohlin, P. O. Hesselborn, \& P. M. Wijkman (eds.). The International Allocation of Economic Activity. London: Macmillan.

Dunning, J. H. 1988. Explaining International Production. London: Harper Collins.

Ginevičius, R.; Butkevičius, A.; Podvezko, V. 2005. Naujų Europos Sajungos šalių ekonominès plètros daugiakriterinis 
ivertinimas [Multicriteria evaluation of economic development of new EU Member-States], Business: Theory and Practice [Verslas: teorija ir praktika] 6(2): 85-93.

Ginevičius, R.; Podvezko, V. 2005. Daugiakriterinio vertinimo rodiklių sistemos formavimas [Generation of a set of evaluation criteria], Business: Theory and Practice [Verslas: teorija ir praktika] 6(4): 199-207.

Ginevičius, R.; Tvaronavičienè, M. 2003. Čo privádza priame zahraničné Investicie do pobaltských krajin? Pripad Litvy, Lotyšska a Estónska [What Drives Foreign Direct Investments into Baltic Countries? The Case of Lithuania, Latvia and Estonia], Ekonomický Časopis [Journal of Economics] 51(8): 963-981.

Ginevičius, R.; Tvaronavičienè, M. 2004. Risk of globalization: case study of Lithuanian economy, Ekonomický Časopis [Journal of Economics] 52(2): 212-231.

Ginevičius, R.; Tvaronavičienè, M.; Korsakienè, R.; Kalašinskaite, K. 2007. Lithuania-Belarus economic relations: how the EU accession impacted bilateral trade, Journal of Business Economics and Management 8(2): 137-145.

Kottaridi, C. 2005. The core-periphery pattern of FDI-led growth and production structure in the EU, Applied Economics 37(1): 99-113.

Statistical Office of Estonia. Available from Internet: <http:// www.stat.ee>.

Statistics Lithuania. Available from Internet: $<$ http://www. stat.gov.lt/lt>.

Steelmaking economics. International labour cost comparisons. Available from Internet: $<\mathrm{http} / / / \mathrm{www}$.steelonthenet. com/labour_cost.html>.

The Energy and Resources Institute (TERI). Available from Internet: $<$ http://www.teriin.org $>$.
The World Bank group. Available from Internet: < www. doingbusiness.org).

Tvaronavičiene, M. 2006. Investment driving forces affecting Lithuanian economic growth, Journal of Business Economics and Management 7(2): 69-77.

Tvaronavičienè, M.; Ginevičius, R. 2005. Emigration tendencies after entering the EU: implications of a qualified workforce loss, in Monash Engineering Education Series: Forum Proceedings: UICEE $4^{\text {th }}$ Asia-Pacific Forum on Engineering and Technology Education. Bangkok, Thailand 26-29 September, 115-119.

Tvaronavičienè, M.; Degutis, M. 2007. If approach to innovations differs in locally and foreign owned firms: case of Lithuania, Journal of Business Economics and Management 8(3): 195-203.

Tvaronavičienè, M.; Ginevičius, R.; Grybaitè, V. 2008. Baltijos šalių išsivystymo palyginimas: praktiniai kompleksinio požiūrio taikymo aspektai, [Comparisons of Baltic countries development: practical aspects of complex approach], Business: Theory and Practice [Verslas: teorija ir praktika] 9(1): 51-65.

Tvaronavičienè, M.; Grybaite, V. 2007. Impact of FDI on Lithuanian economy: insight into development of main economic activities, Journal of Business Economics and Management 8(4): 285-290.

Tvaronavičius, V.; Tvaronavičienè, M. 2008. Role of fixed investments in economic growth of country: Lithuania in European context, Journal of Business Economics and Management 9(1): 57-65.

Yoshitomi, M.; Graham, E. 1996. Foreign Direct Investment in Japan. Cheltenham: Edward Edgar Publishing Limited.

Zavadskas, E. K.; Ustinovičius, L.; Peldschus, F. 2003. Development of software for multiple criteria evaluation, Informatica 14(3): 259-272. 